\title{
Cine y Pediatría (II): infancia y adolescencia en las pantallas de cine de todo el mundo
}

\author{
J. González de Dios \\ Servicio de Pediatría. Hospital General Universitario de Alicante. Departamento de Pediatría. \\ Universidad Miguel Hernández. Alicante. España.
}

Según la Comisión Nacional de la Especialidad de Pediatría y sus Áreas Específicas, se define la pediatría como la medicina integral del periodo evolutivo de la existencia humana desde la concepción hasta el final de la adolescencia, época cuya singularidad reside en el fenómeno de crecimiento, maduración y desarrollo biológico, fisiológico y social que, en cada momento, se liga a la íntima interdependencia entre el patrimonio heredado y el medio ambiente en el que el niño se desenvuelve.

Con esa definición, imaginemos el caudal de guiones que se pueden aplicar al "séptimo arte" relacionados con la pediatría, entendiendo como tal aquellas películas que tengan a niños y adolescentes como personajes principales, en estado de salud o enfermedad y alrededor de su entorno social.
Y así ha sido. Películas que hablan sobre enfermedades infantiles, bien como argumento central o periférico: defectos congénitos, enfermedades genéticas, enfermedades degenerativas, enfermedades oncológicas, enfermedades neurológicas, etc. Películas que se centran en temas alrededor de problemas de la infancia: maltrato infantil, marginación y pobreza, analfabetismo, adopción, delincuencia, drogadicción, etc. Películas cuyos personajes centrales son niños, con distintas edades, y a través de sus ojos nos devuelven la visión de sus familias o de la sociedad en que se desenvuelven, sociedades del primer y también del tercer mundo, sociedades próximas y sociedades exóticas. Adelantamos que, entre las distintas etapas de la infancia, la adolescencia se convierte, por derecho propio, en

Javier González de Dios: javier.gonzalezdedios@gmail.com

El autor declara no presentar conflictos de intereses en relación con la preparación y publicación de este artículo . 
un tema central dentro de la conexión entre cine y pediatría.

Podríamos haber elegido muchas formas de presentar una pequeña selección (a buen seguro incompleta e imperfecta) sobre películas de cine y pediatría, seleccionadas en base a los "criterios de inclusión" previamente expuestos. Pero hemos elegido un concepto temporal (sólo películas estrenadas en la última década) y las hemos clasificado por países, para confirmar que el fenómeno es global.

Cuando clasificamos las películas por países percibimos cuatro grupos, según el aflujo de películas de cada país a nuestras carteleras:

a) Dos filmografías predominantes: España y Estados Unidos. Se corresponde con la abusiva presencia de películas de estos países en nuestras pantallas.

b) Tres filmografías europeas destacadas: Francia, Italia y Reino Unido. Son los tres países de la Unión Europea que más estrenan en España, eso sí, a gran distancia de las películas made in USA.

c) Dos filmografías peculiares: Argentina e Irán. El cine argentino sigue manteniendo un gran pulso y es el único país no europeo que, a excepción de los cinco previa- mente citados, estrena con mayor asiduidad en nuestro país. El cine iraní supone globalmente un punto de vista alternativo al hollywoodiense en lo estético, en lo temático y en lo narrativo. En lo estético, porque apuesta por una depuración de la imagen que prescinde de todo efectismo y de toda superficialidad; en lo temático, porque bucea en la sencillez de la vida cotidiana; y también es una alternativa en lo narrativo porque parte de unos modelos de guión y de héroe al margen de los patrones clásicos. Dos características más del cine iraní: la implicación del espectador por el uso del fuera de campo (hay mucho cine alrededor de la pantalla que el espectador debe incorporar con su imaginación) y, sobre todo, la importancia que tienen las miradas de los niños en el cine iraní, miradas limpias con las que quiere identificarse el ojo de la cámara y mostrar historias. Irán merece un apartado especial cuando hablamos de cine y pediatría, pues pocas cinematografías han utilizado tanto (y tan bien) a los niños en sus películas. El cine iraní posee preciosas películas, no exentas 
tampoco de imágenes de dureza y desamparo, símil poético de situaciones sociales reales, de las que no escapan los niños. Niños no actores que se encarnan como protagonistas de muchas de las películas que han conformado en los últimos 15 años la parte más conocida de la denominada Iranian New Wave del cine y en el que destacan los nombres de Abbas Kiarostami (¿Dónde queda la casa de mi amigo?, 1987), Jafar Panahi (El espejo, 1997), Majid Majidi (El color del paraíso, 1999), Bahman Ghobadi (Las tortugas también vuelan, 2004), y la familia Makhmalbaf, que incluye a Mohsen Makhmalbaf (El silencio, 1997), Samira Makhmalbaf (La manzana, 1998), Hana Makhmalbaf (Buda explotó por vergüenza, 2007) y un largo etcétera.

d) Filmografías anecdóticas: en el resto de países.

En la posterior relación indicamos con un asterisco $\left({ }^{*}\right)$ aquellas que consideramos de especial valor, no sólo por su valor artístico, sino preferentemente por el valor como recurso docente para la humanización y mejora de la relación médico-paciente.

\section{Dos filmografías predominantes}

\section{España}

- ${ }^{*}$ El Bola (Achero Mañas, 2000): el problema de los malos tratos a los niños y la violencia doméstica a través de las vivencias de El Bola, un niño de 9 años que vive en un barrio obrero de Madrid.

- *a espalda del mundo (Javier Corcuera, 2000): tres historias en forma de documental sobre personas a las que les han robado la vida, la palabra o la infancia. Esta última historia narra la experiencia de un grupo de niños que se ganan la vida picando piedra en una cantera en la periferia de Lima.

- Más pena que gloria (Víctor García León, 2001): vivencias familiares, escolares y amorosas de un adolescente. Una adolescencia que transcurre con más pena que gloria en tono de comedia.

- ${ }^{*}$ Planta 4. ${ }^{2}$ (Antonio Mercero, 2003): relato pseudoautobiográfico de un adolescente con un osteosarcoma y su vida en una planta de oncología pediátrica (figura 1).

- ${ }^{*}$ En el mundo, a cada rato (2004): la película, realizada como una contribución del cine a la protección de los derechos de la infancia 
en el mundo, se compone de 5 historias, que abordan las 5 prioridades de UNICEF en este ámbito: la lucha contra el sida (El secreto mejor guardado, de Patricia Ferreira), filmada en la India; la inmunización del paludismo (La vida efímera, de Pere Joan Ventura), filmada en Guinea Ecuatorial; la atención integral a la primera infancia (Las siete alcantarillas, de Chus Gutiérrez), filmada en Argentina; la protección de la infancia (Hijas de Belén, de Javier Corcuera), filmada en Perú; la educación para las niñas (Binta y la gran idea, de Javier Fesser), filmada en Senegal.

- *León y Olvido (Xavier Bermúdez, 2004): dos hermanos mellizos, huérfanos desde hace cinco años. León tiene síndrome de Down y Olvido no le quiere a su lado, porque no quiere ataduras y quiere que su hermano tome sus propias decisiones y aprenda a valerse por sí mismo, pero León sólo desea sentirse protegido y atendido por su hermana.

- El juego del ahorcado (Manuel Gómez Pereira, 2008): Sandra y David

Figura 1. Planta 4. ${ }^{\mathrm{a}}$ (Antonio Mercero, 2003).

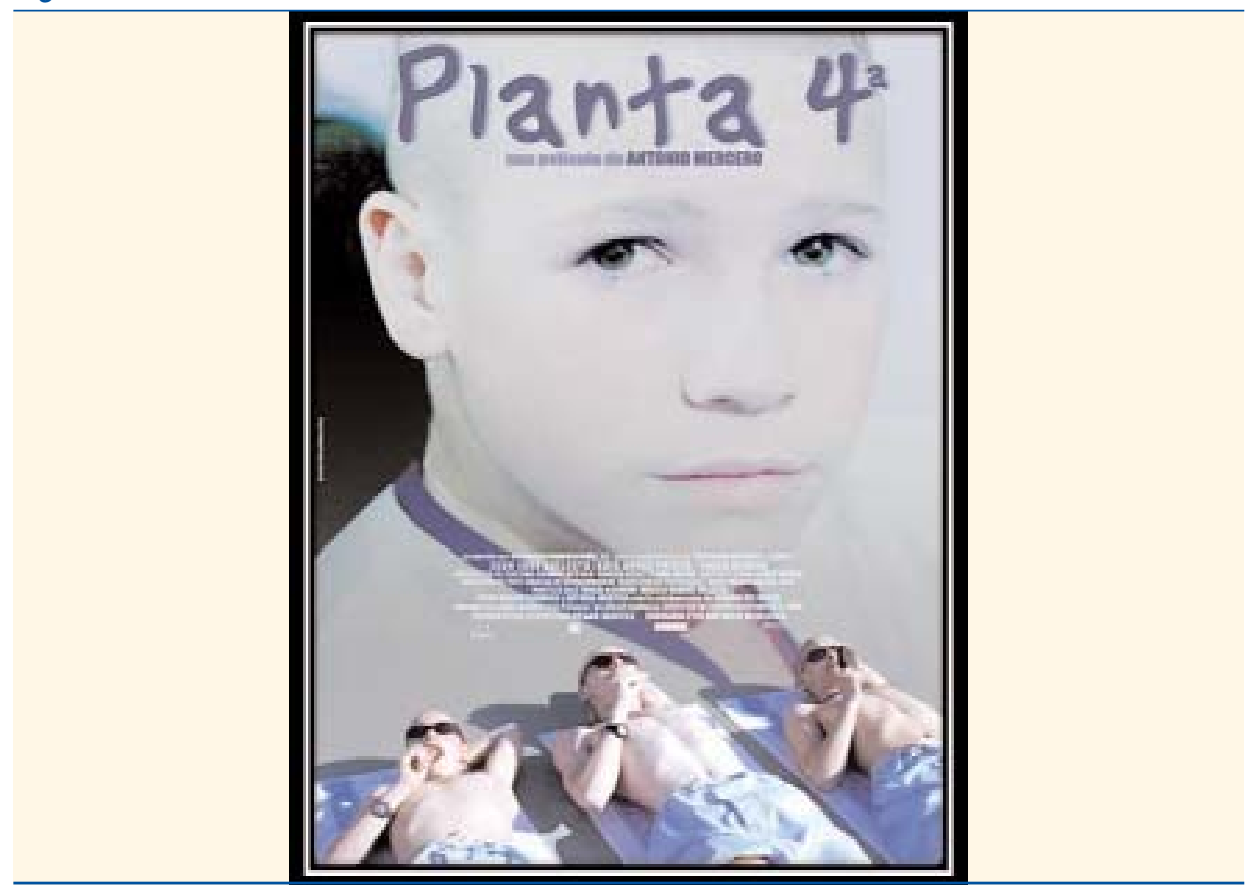


son amigos y compañeros de aventuras desde la infancia. Cuando alcanzan la adolescencia, parece lógico que su amistad derive en una relación más profunda, pero un acontecimiento imprevisible golpea brutalmente a cada uno por separado, alterando el curso que seguían sus vidas de estudiantes.

- ${ }^{*}$ Camino (Javier Fesser, 2008): aventura emocional en torno a una deslumbrante niña de 11 años, de familia muy religiosa, que se enfrenta al mismo tiempo a dos acontecimientos que son completamente nuevos para ella: enamorarse y morir (por una enfermedad oncológica).

- *a vergüenza (David Planell, 2009): trata con rigor el problema de la acogida/adopción de un niño en la familia: Manu, el niño de 8 años peruano con trastorno del comportamiento que acogieron hace un año, les viene grande $y$ han decidido devolverlo.

- Yo también (Álvaro Pastor y Antonio Naharro, 2009): Daniel tiene síndrome de Down, comienza a trabajar en la administración pública y conoce a una compañera, Laura, bebedora, divertida, promiscua y con un pasado que ha decidi- do olvidar. Ambos inician una relación de amistad que pronto se convierte en un problema para Laura, cuando Daniel se enamora de ella.

\section{Estados Unidos}

- *Duo: The True Story of a Gifted Child with Down Syndrome (Alexandre Ginnsz, 1996): película independiente estadounidense, narra la historia de un niño de 12 años con síndrome de Down que se enamora de una niña de su misma edad.

- El indomable Simon Birch (Mark Steven Johnson, 1998): la amistad entre dos niños de 12 años (Joe y Simon; este último, afecto de enanismo secundario a una enfermedad de Morquio) y su infancia y aventuras. Joe busca la identidad de su padre, un secreto que su madre ha guardado toda su vida y Simon decide ayudar a su amigo a encontrar a su padre.

- Las normas de la casa de la sidra (Lasse Hallstöm, 1999): Homer Wells es un huérfano que ha crecido en el orfanato de St. Cloud's bajo la poco convencional, pero tierna tutela del Dr. Wilbur (curioso profesional de la medicina, mitad pediatra, mitad ginecólogo). 
Pero a medida que Homer se va haciendo un hombre y se da cuenta del gran abanico de posibilidades que le brinda la vida, empieza a dudar y a cuestionar los métodos de su mentor.

- Boys Don't Cry (Kimberly Peirce, 1999): película dramática de cine independiente basada en la historia real de Brandon Teena, un joven transexual que fue violado y asesinado por sus amigos masculinos cuando descubrieron que tenía genitales femeninos.

- Up Syndrome (Duane Graves,
2000): película documental acerca de la vida de un chico con síndrome de Down, que supuso un enorme éxito en su país.

- John Q (Nick Cassavetes, 2001): crítica al sistema de seguros médicos estadounidense, a través de un padre que precisa urgentemente un trasplante de corazón para su hijo (afecto de una miocardiopatía hipertrófica) y para conseguirlo secuestra y bloquea el servicio de urgencias de un hospital.

- La casa de los babys (John Sayles, 2003): seis mujeres norteamerica-

Figura 2. Elephant (Gus van Sant, 2003).

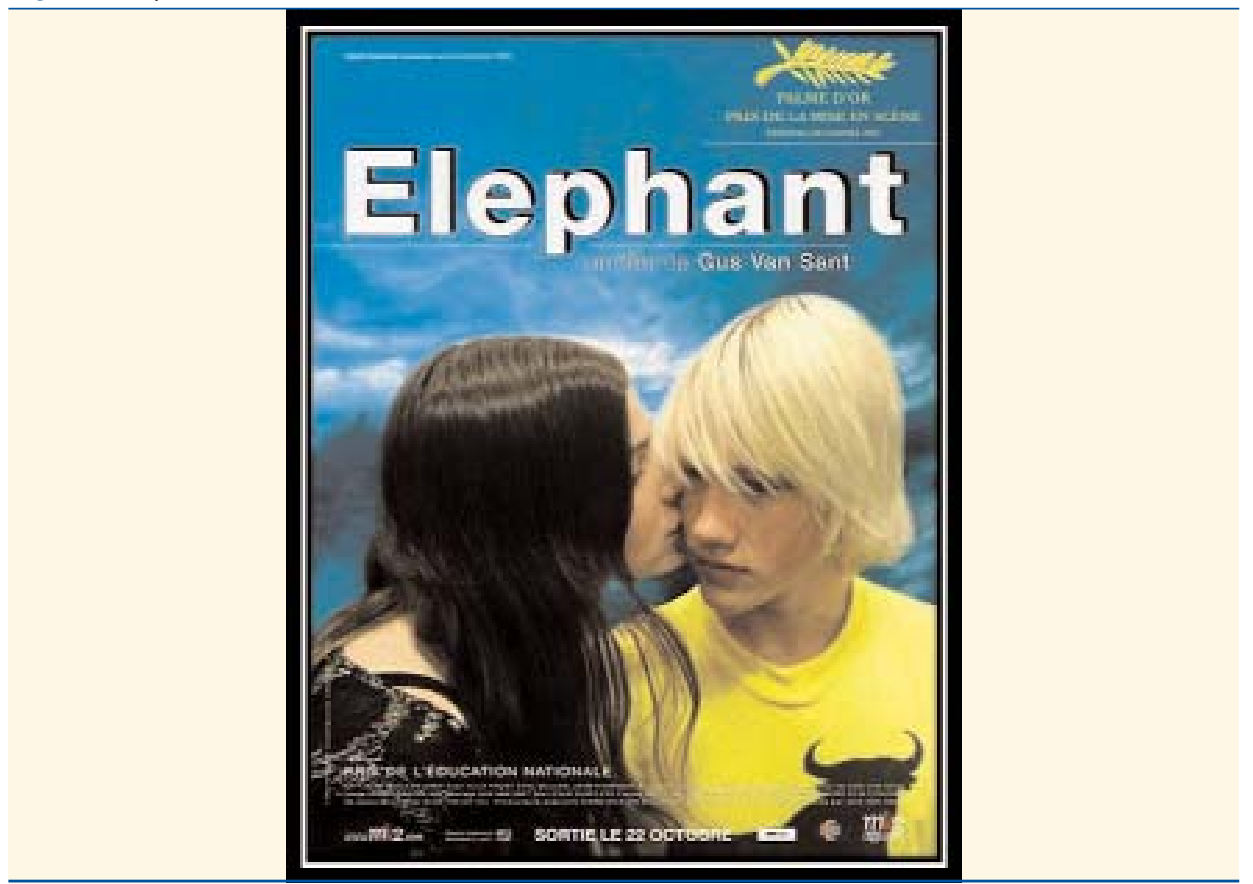


nas hospedadas en un exótico motel sudamericano en uno de los momentos emocionalmente más importantes de sus vidas; todas se hallan esperando el momento en que se les va a hacer entrega de un bebé en adopción de un orfanato local. Una ácida, inteligente y profunda visión del choque de culturas, la maternidad moderna y los misterios que nos depara el destino.

- ${ }^{*}$ Elephant (Gus van Sant, 2003): sienta sus bases en la masacre de Columbine (donde dos estudiantes asesinaron a trece compañeros), un hecho que conmocionó a Estados Unidos y al que Michael Moore dedicó su documental Bowling For Columbine (figura 2).

- ${ }^{*}$ Thirteen (Catherine Hardwicke, 2004): afilado retrato de la adolescencia, a través de la transformación de una niña de 13 años que pasa de tener peluches en la habitación a experimentar con los piercings, las drogas y el sexo, en base a la influencia de la chica más popular del instituto.

- Hard Candy (David Slade, 2005): thriller psicológico entre una adolescente de 14 años y un fotógrafo en la treintena que se encuen- tran en una cita en el chat. Funciona como un aviso a la pederastia.

- El niño de Marte (Menno Meyjes, 2007): un escritor de ciencia ficción que ha enviudado recientemente, está considerando adoptar a Dennis, un pequeño niño huérfano que dice ser del planeta rojo $y$ tiene una conducta bastante extraña. Sin embargo, sea cual sea el origen real de este increíble pequeño, se siente cada vez más apegado a él y experimenta el poder transformador del amor parental.

- *Juno (Jason Reitman, 2007): una adolescente de 16 años descubre que está embarazada de su amigo. Aunque inicialmente decide abortar, en el último momento $y$ tras muchas peripecias opta por dejar nacer al bebé y darlo en adopción. La película fue interpretada como un mensaje a favor de la vida (figura 3).

- Chop Shop (Ramin Bahrani, 2007): historia de dos hermanos huérfanos de origen latino que se ganan la vida trabajando en lo que pueden: él en un taller y ella sirviendo comida de día y prostituyéndose de noche. Las circunstacias de la vida han hecho que los niños maduren 
antes de tiempo y se convierta en el responsable de su familia cuando, lo que debería estar haciendo, es jugar y estudiar.

- *Precious (Lee Daniels, 2009): un relato duro y vibrante de una adolescente negra de 16 años con obesidad mórbida, analfabeta y que vive en el Harlem de los años ochenta desarraigada socialmente junto a su madre, una expresidiaria que la somete a maltratos físicos y emocionales. Es trasladada a un instituto alternativo donde los alumnos participan activamente en la enseñanza; allí conocerá a una profesora que no parará hasta que Precious recupere su dignidad.

- * La decisión de Anne (Nick Cassavetes, 2009): una niña de tres años es diagnosticada de leucemia promielocítica aguda. En la lucha ininterrumpida por salvar a esta hija, los padres programan la gestación de una nueva hija con el objetivo de paliar las carencias del organismo enfermo de su hermana mayor, según indicaciones médicas. Cine con conciencia políti-

Figura 3. Juno (Jason Reitman, 2007).

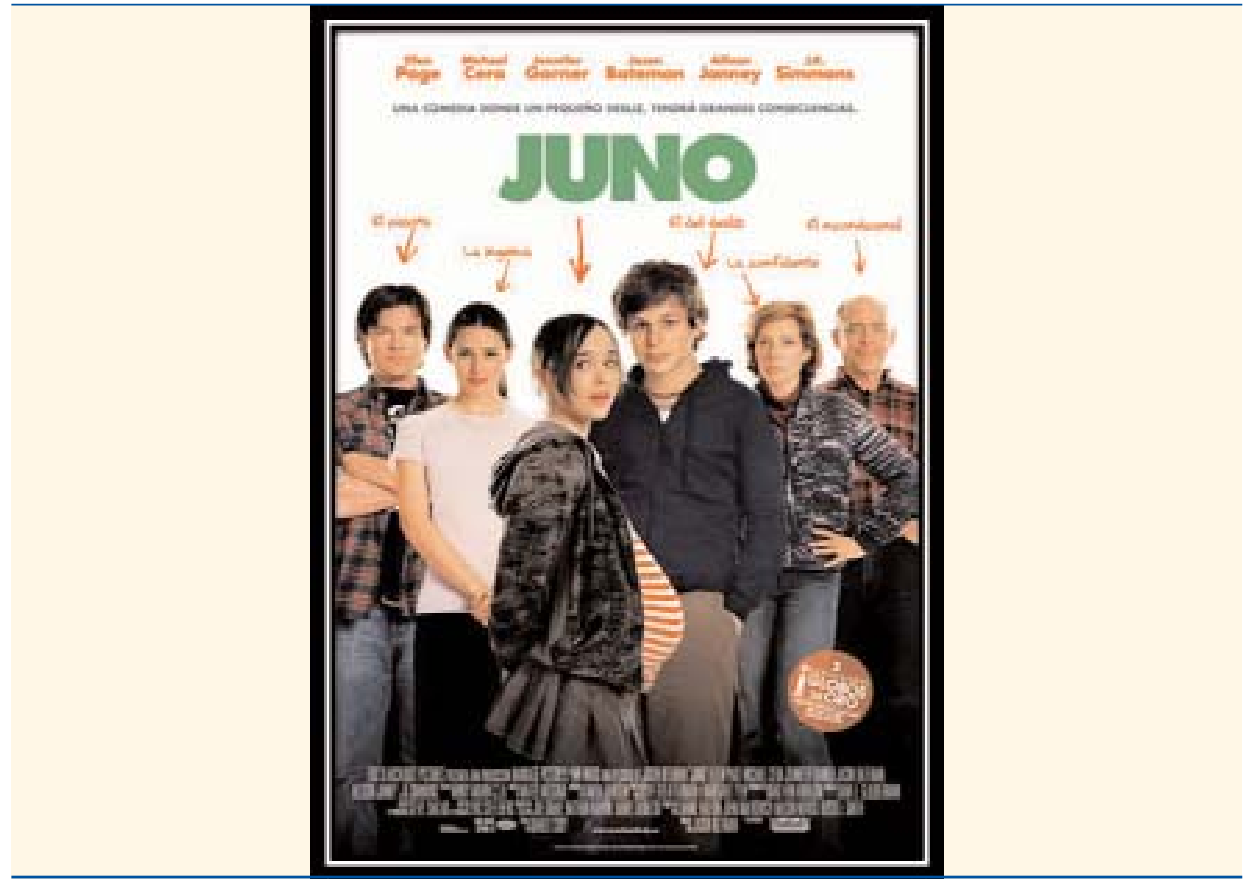


cosocial, que se esmera en esbozar un discurso responsable acerca de los límites éticos de la medicina y los límites morales en la utilización de organismos sanos para la sanación de organismos enfermos.

\section{Tres filmografías europeas destacadas}

\section{Francia}

- A ma soeur (Catherine Breillat, 2000): psicodrama sobre el descubrimiento sexual de la adolescencia y la historia de rivalidad de dos hermanas, una de 15 años esbelta y promiscua y la otra de 12 años obesa y hogareña.

- *La pequeña Lola (Bertrand Tavernier, 2004): las peripecias de una pareja francesa de clase media que viaja a Camboya para cumplir el sueño de adoptar un niño. Para ellos se inicia una aventura agotadora: visados falsificados, visitas a orfanatos inhumanos, extorsiones y estafas, enfrentamientos con las autoridades francesas y camboyanas $\mathrm{O}$ amenazas de traficantes. $\mathrm{A}$ través de esta peregrinación, la

Figura 4. Persépolis (Vicente Paronnaud, 2007).

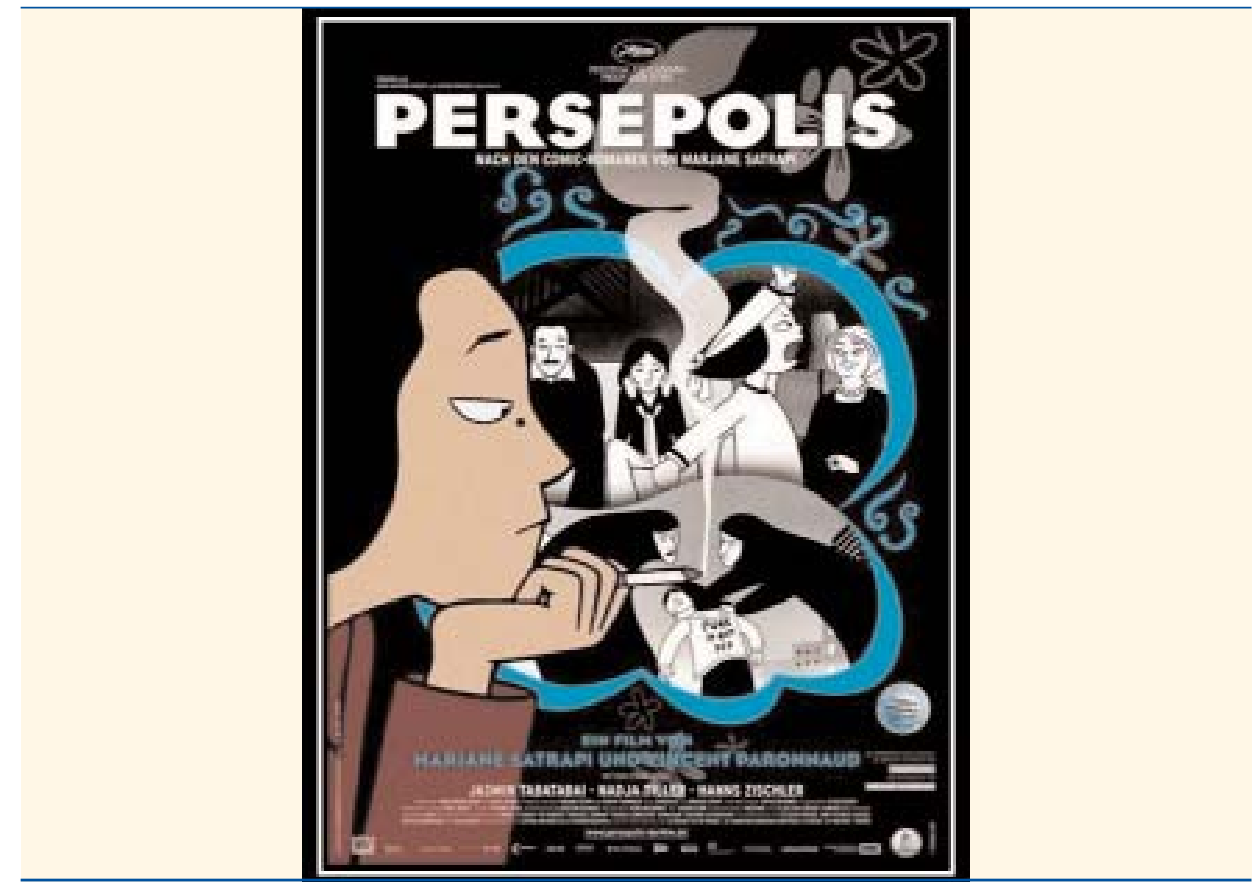


pareja se enfrenta a sus propios miedos, a sus egoísmos, sin olvidar la desconfianza y la envidia, aunque también la ayuda mutua de la pequeña comunidad de futuros padres adoptivos que el azar ha reunido en ese país.

- Los chicos del coro (Christophe Barratier, 2004): la música transforma el interés y la vida de los niños en un represivo internado francés tras la Segunda Guerra Mundial.

- Vete y vive (Radu Mihaileanu, 2005): miles de refugiados africa- nos llegan a los campamentos de Sudán. Una madre cristiana convence a su hijo de 9 años para que diga que es judío y así salvarle de la hambruna y de una muerte segura. Oficialmente es huérfano y le adopta una familia sefardí francesa afincada en Tel Aviv. Descubrirá el amor, la cultura occidental y el judaísmo por un lado, y el racismo y la guerra en los territorios ocupados por otro. Pero nunca olvidará a su auténtica madre, la que se quedó en el campamento, y siempre soñará con encontrarla de nuevo.

Figura 5. La clase (Laurent Cantet, 2008)

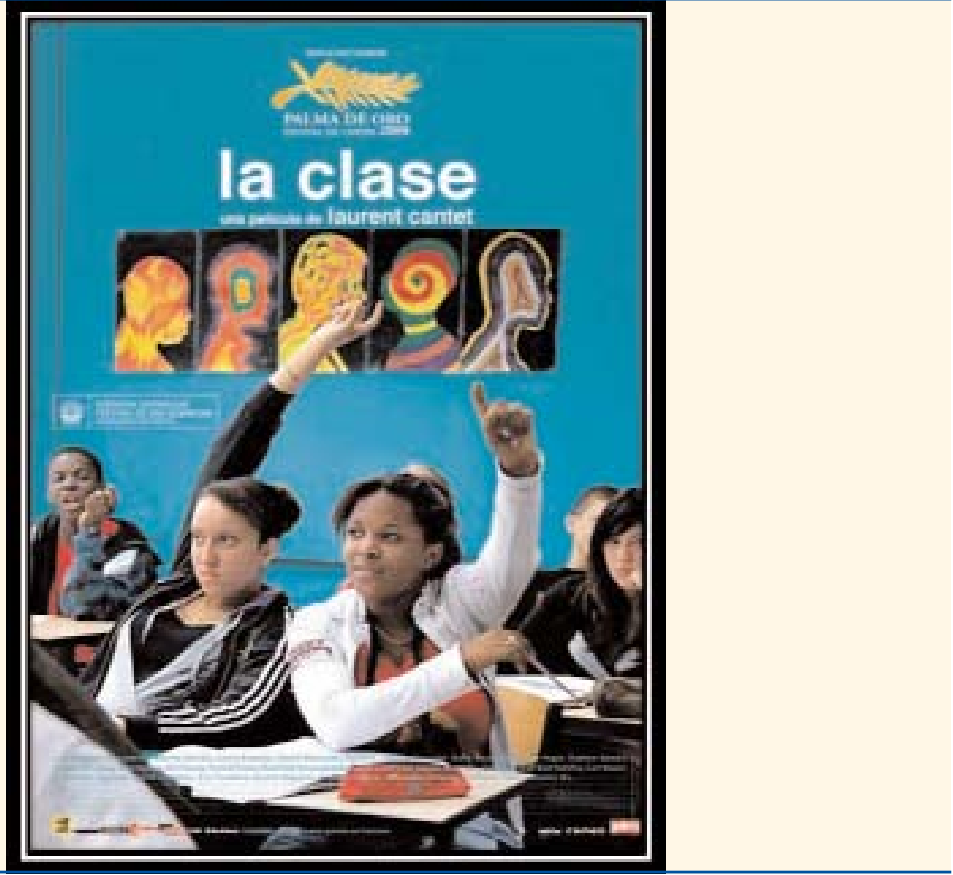


- La culpa es de Fidel (Julie Gravas, 2006): narra la infancia de una pequeña burguesa, que con 9 años ve como todo su universo se tambalea, pero su comprensión del mundo se enriquece. Esta es una película con tono político contada con delicadeza y sin excesos.

- *Persépolis (Vicente Paronnaud, 2007): Marjane es una niña que vive en el Irán de los años setenta, en una familia occidentalizada. Esta historia comienza cuando los fundamentalistas toman el poder de manera autoritaria y surge la llamada revolución islámica, obligando a las mujeres a llevar velo y encarcelando a miles de personas. Persépolis es una pequeña y curiosa joya, conserva en todo momento un envidiable sentido del humor que evita el victimismo y el lamento. Un recorrido apasionante por el Irán de los años ochenta y principios de los noventa, visto por los ojos de una niña que se hace adulta a marchas forzadas en un contexto muy complicado (figura 4).

- ${ }^{*}$ La clase (Laurent Cantet, 2008): película con formato de docudrama sobre las relaciones de un joven profesor de lengua francesa en un instituto difícil, con alumnos de 14 y 15 años, situado en un barrio conflictivo. Hiperrealismo y credibilidad sobre las difíciles relaciones profesor y alumnos en nuestros institutos (figura 5).

- El erizo (Mona Achache, 2009): la visión de la vida de los habitantes de un inmueble en París, revisitado a través de Paloma Josse, una niña de 11 años tremendamente inteligente y alrededor de la cual giran los sentimientos de los adultos.

Italia

- *a habitación del hijo (Nanni Moreti, 2001): una historia simple que llega directa al corazón, al relatarnos los sentimientos de una familia tras la muerte de un hijo.

- *as llaves de la casa (Gianni Amelio, 2004): conmovedora historia de Paolo, un niño con parálisis cerebral infantil, quien debe viajar a un hospital especial en Berlín y al que le acompaña su padre, quien le abandonó en su infancia. Alí se encuentran con Nicole, una madre que ha dedicado su vida por completo al cuidado de su hija, también discapacitada, y que ayudará a este padre con sentimientos de culpa (figura 6). 
- Melissa P (Luca Guadagnino, 2005): adaptación al cine de un exitoso y polémico libro autobiográfico sobre la aventuras sexuales de una adolescente siciliana en plena etapa de experimentación de camino hacia la madurez.

- Libero (Kim Rossi Stuart, 2006): dos niños y su padre forman una extraña familia tras ser abandonados por la mujer más importante de sus vidas: su madre y esposa. Para los tres, en este hogar incompleto, se ha instalado una paz rutinaria. Pero cuando la madre rea- parece, se altera el precario equilibrio de la familia, removiéndose el dolor enterrado, y es cuando el hijo mayor de 11 años adquiere un papel clave.

- Caterina se va Roma (Paolo Virzi, 2003): cuenta la aventura en la capital de la familia lacovoni, con una crítica bastante dura sobre las clases sociales, la educación, la incomunicación entre la gente, la amistad y la familia ante los ojos de una niña de 12 años que intenta sobrevivir en un mundo tan complejo.

Figura 6. Las llaves de la casa (Gianni Amelio, 2004).

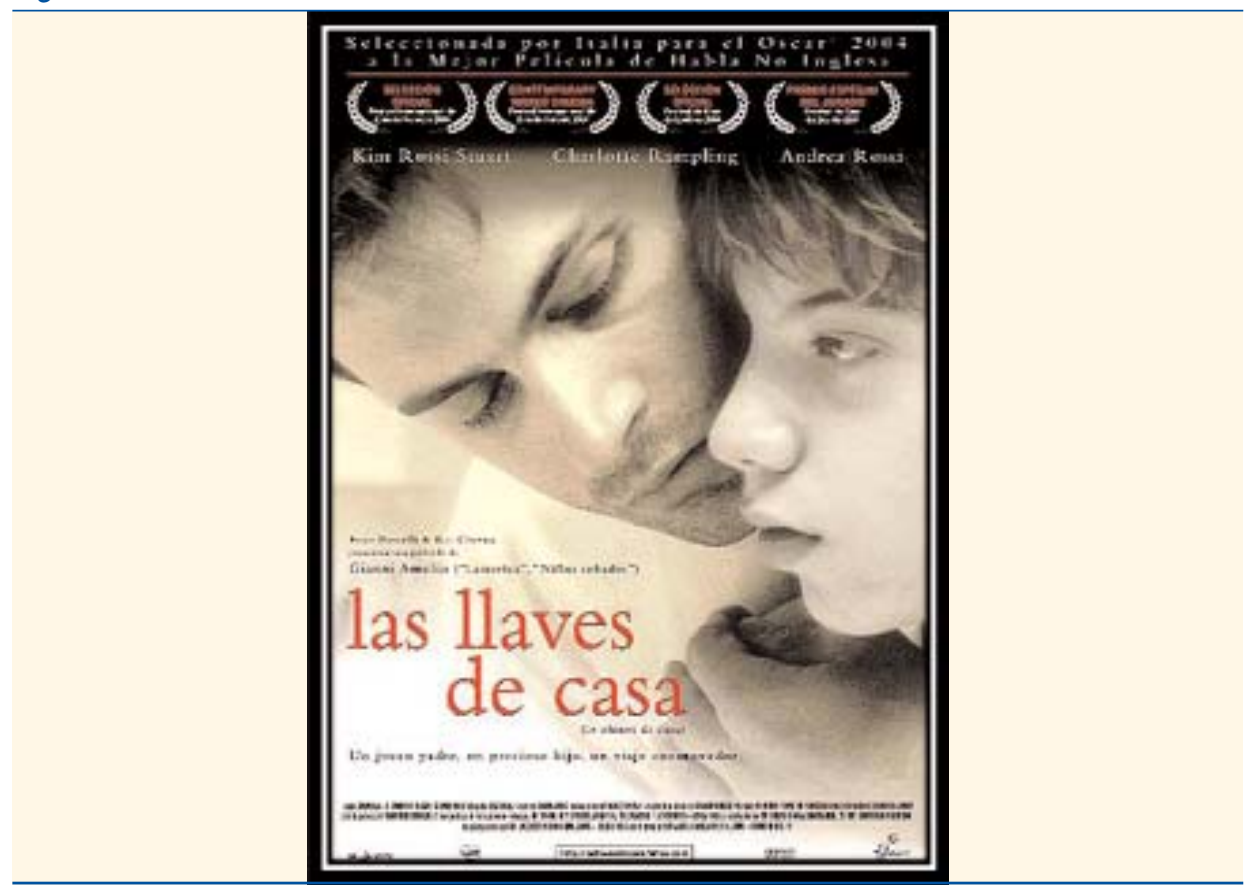




\section{Reino Unido}

- *Slumdog millionaire (Danny Boyle, 2008): pocas películas han sido capaces de contar tantas desgracias alrededor de la infancia (pobreza, marginación, delincuencia y prostitución juvenil, maltrato y mafias de niños, etc.) y simular un cuento de hadas en las calles de Bombay, con un final feliz que despierta una sonrisa y energía positiva. Hollywood y Bollywood se unen en esta película con tintes dickensianos y a través de tres edades de la infancia: 7, 13 y 18 años.

- El niño con el pijama de rayas (Mark Herman, 2008): historia de una inverosímil amistad entre dos chicos de 9 años que viven a ambos lados de un campo de concentración: Bruno, hijo de un general alemán, y Shmuel, un chico judío que vive una extraña existencia paralela al otro lado de la alambrada.

- After Life (Alison Peebles, 2003): historia de una madre y sus dos hijos (Kenny y Roberta). Roberta presenta síndrome de Down y es el orgullo y alegría de su madre; es una niña feliz con la vida que le ha tocado. Kenny es periodista con una carrera en ascenso y un posible futuro profesional fuera de su país. Sin em- bargo, su vida cambia cuando enferma la madre y tiene que hacerse cargo del cuidado de su hermana.

- *Fish tank (Andrea Arnold, 2010): nos presenta el mundo particular de Mia, una adolescente de 15 años que habita una de esas viviendas colmena en una población obrera inglesa, una chica enfadada con su vida, su familia y con el mundo... y que encuentra tan sólo en el baile (el rap y el hip hop) una vía de escape para huir de la sensación de asfixia de su día a día y del desarraigo familiar en el que ha debido crecer (figura 7).

\section{Dos filmografías peculiares}

\section{Argentina}

- Buenos Aires 100 Km (Pablo José Meza, 2004): el paso de la infancia a la adolescencia con cinco chicos en un pueblo alejado $100 \mathrm{~km}$ de Buenos Aires. Sus experiencias con las chicas, la rebeldía con los padres, los secretos en esta etapa de cambio en que nada es eterno, ni siquiera la amistad.

- ${ }^{*}$ El polaquito (Juan Carlos Desanzo, 2004): adolescente buscavidas en la ciudad de Buenos Aires y su relación con una jovencita, prostitu- 
ta por necesidad. Tragedia a ritmo de tango, un tango triste de una triste historia de adolescentes perdidos en una sociedad perdida en el patio trasero de nuestras ciudades, que no siempre queremos visitar.

- La niña santa (Lucrecia Martel, 2004): una colegiala católica adolescente tiene la revelación religiosa de salvar del pecado al hombre que le ha descubierto su propia sexualidad a partir de un encuentro procaz.

- Nordeste (Juan Solana, 2005): un viaje iniciático de una mujer france- sa de 45 años para adoptar un niño en Argentina. Descubre la belleza de esa tierra y sus habitantes, en violento contraste con la miseria y corrupción que hace posible la venta de niños en el negocio de la adopción internacional ilegal.

- *XXY (Lucía Puenzo, 2007): cuenta, con sensibilidad y respeto, la historia de Alex, una adolescente intersexual de 15 años que, junto con sus padres, huye de Buenos Aires a una pequeña villa frente al mar en la desembocadura del Río de la Plata para evitar ser rechaza-

Figura 7. Fish tank (Andrea Arnold, 2010).

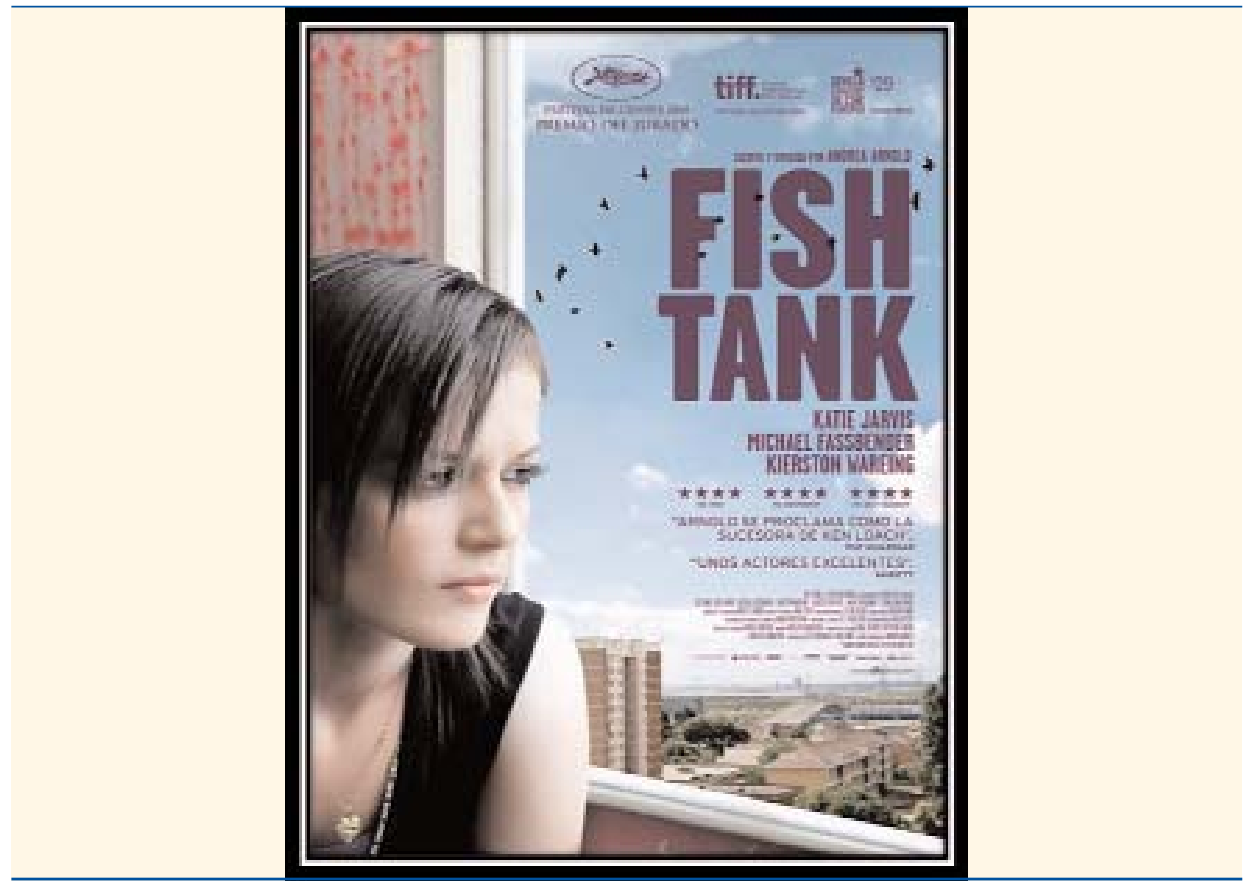


da por la sociedad y aprender a aceptar su condición. Un personaje lleno de aristas, pero bello y conmovedor (figura 8).

- Leonera (Pablo Trapero, 2008): sólido drama de una joven encarcelada y la relación que desarrolla con su hijo, que nace en la cárcel y al que debe criar en condiciones difíciles. Niños alrededor del mundo carcelario, sin moralina, sin manipular al espectador.

- Anita (Marcos Carnevale, 2009): historia de una joven con síndrome de Down que vive con su ma- dre en un barrio de Buenos Aires y se pierde en la ciudad.

Irán

- Barán (Majid Majidi, 2001): historia de refugiados afganos contada a través de los ojos de Lateef, un pícaro adolescente con un gran corazón. Trabaja como portero en una construcción, proporcionando té y comida a los trabajadores afganos que trabajan ilegalmente por un salario escaso.

- *Las tortugas también vuelan (Bahman Chobadi, 2004): un grupo de

Figura 8. XXY (Lucía Puenzo, 2007).

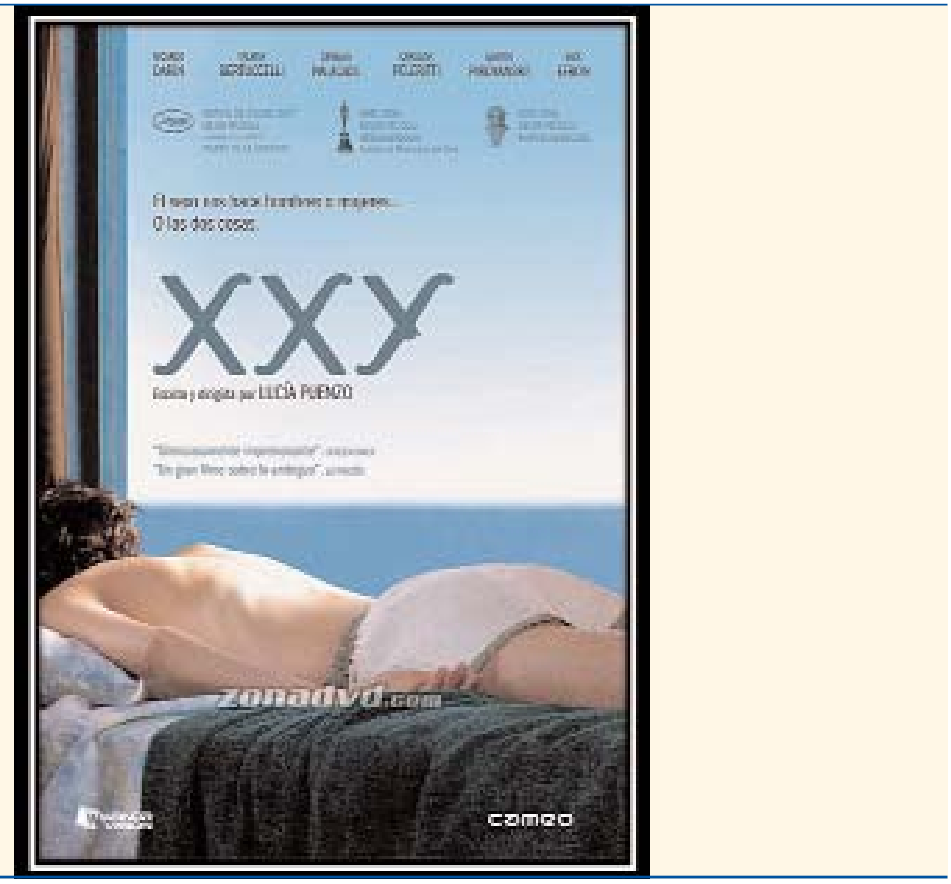


niños huérfanos con taras reales (agenesia de ambos brazos, ciegos por glaucoma congénito, cojos por las bombas, etc.) se ganan la vida en el Kurdistán vendiendo minas antipersonales a la ONU, que ellos mismos extraen y de las que han sido víctimas, o canjeándolas por armas en el mercado negro (figura 9).

- *Buda explotó por vergüenza (Hana Makhmalbaf, 2007): cuenta la odisea de Baktay, una niña afgana de 6 años, para comprar un cuaderno y asistir a la escuela; lo que provoca que unos niños, que juegan a ser talibanes, decidan atraparla en una cueva y apedrearla, porque opinan que una niña no debería ir a la escuela. Metáfora sobre la vida de las mujeres en esas comunidades, la guerra y la ausencia de libertad que supone convivir con los talibanes.

\section{Filmografías anecdóticas}

Afganistán

- *Osama (Siddiq Barmak, 2003): la llegada de los talibanes al poder en Afganistán deja a las mujeres

Figura 9. Las tortugas también vuelan (Bahman Ghobadi, 2004).

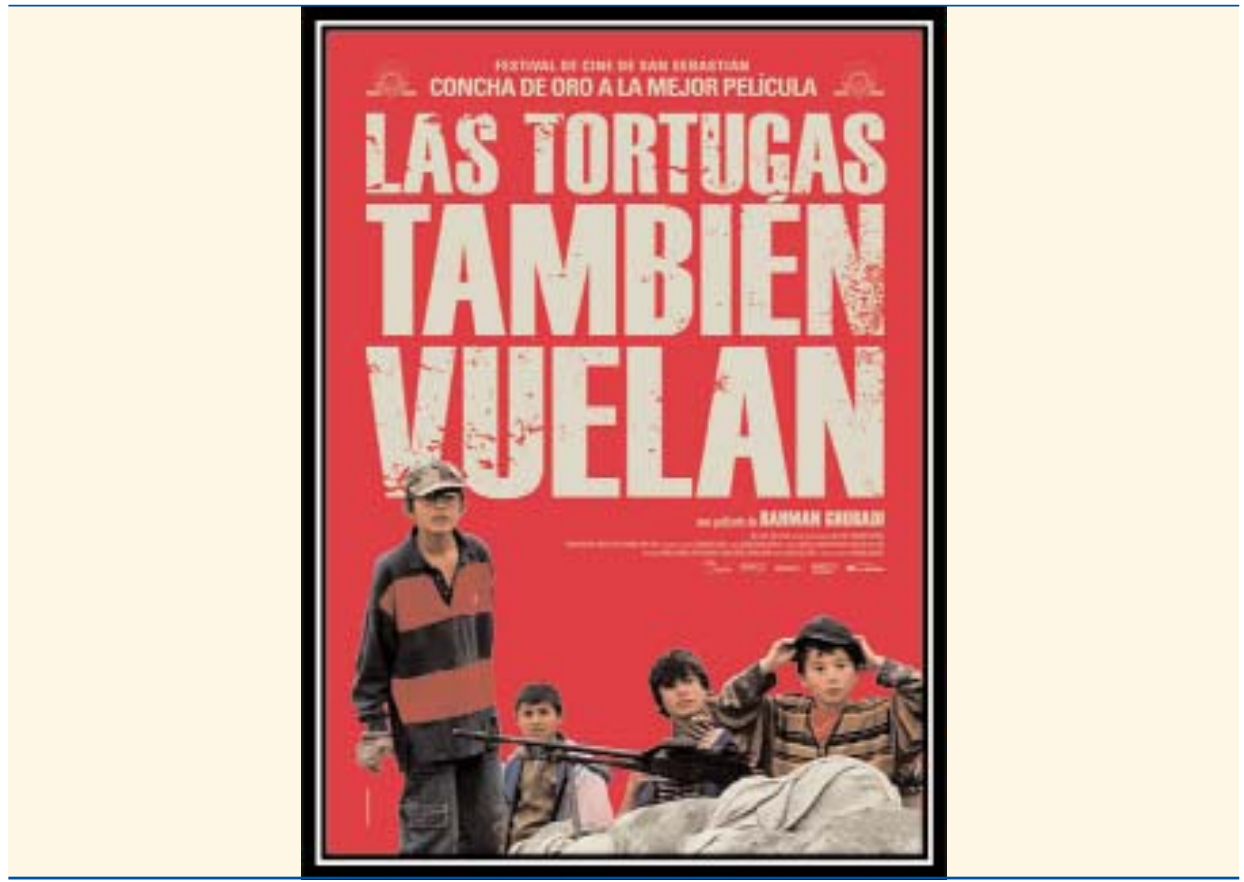


sin derechos a trabajar o a salir solas por la calle, dado que no tienen un varón en la familia que vele por ellas. Es por ello que una niña de 12 años intenta hacerse pasar por un chico en un esfuerzo de mantener a su madre viuda y a su abuela (figura 10).

\section{Alemania}

- *La ola (Dennis Gansel, 2008): reflejo del poder de la educación en la infancia para modificar la conducta y poder crear conductas totalitarias. Basada en el experimento que en 1967 Ron Jones, un profesor de historia de un instituto de Palo Alto en California, llevó a cabo con sus alumnos: instituyó un régimen de extrema disciplina en su clase, restringiéndoles sus libertades y haciéndoles formar en unidad. Se conoció a este movimiento como The Third Wave y fue necesario acabar con el experimento antes de que llegara más lejos.

\section{Australia}

- Romulus, my father (Richard Roxburgh, 2007): basada en las me-

Figura 10. Osama (Siddiq Barmak, 2003).

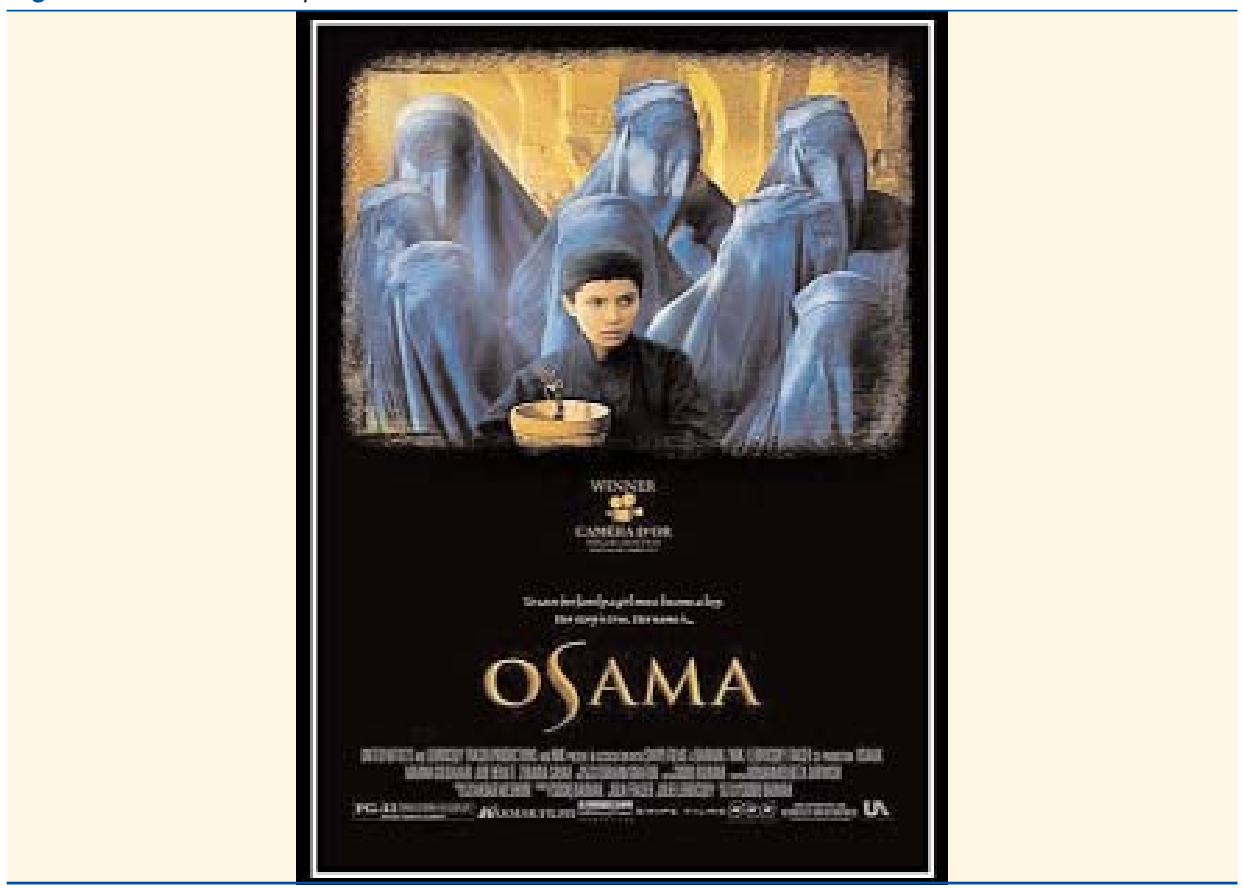


morias de Raimond Gaita, es una película sobre un hombre compasivo y honesto, que enseñó a su hijo el significado de llevar una vida decente. Los ojos del niño son el protagonista que nos muestra un mundo de sentimientos en los mayores con los que aprenderá a crecer.

\section{Austria}

- *La cinta blanca (Michael Haneke, 2009): inquietante reflexión en blanco y negro sobre los orígenes del fascismo, mientras los niños son educados en valores cada vez más absolutos. Radiografía el esqueleto putrefacto de la sociedad alemana de preguerra, del modelo social y educativo que alimentó las brasas de una insólita tolerancia al totalitarismo, a golpes de vara, de desprecios y castigos inmisericordes.

\section{Bélgica}

- El hijo (Luc \& Jean-Pierre Dardenne, 2002): un carpintero a cargo de una escuela de aprendices en un centro de orientación vocacional y reinserción social, es un solitario que un día se ve sorprendido y extremadamente perturbado por la llegada de un nuevo alumno. Obsesivamente lo persigue, lo espía, busca saber de él, quiere y no quiere acercársele.

- Innocence (Lucile Hadzihalilovic, 2004): relato de cómo unas niñas viven encerradas en un internado, entre cuyas paredes permanecen aisladas, sujetas a estrictos rituales, hasta alcanzar la mayoría de edad.

\section{Brasil}

- *Ciudad de Dios (Fernando Meirelles, 2002): desgarradora y violenta visión de la infancia y juventud en la zona de Cidade de Deus, un suburbio de favelas de Río de Janeiro. Talento visual al servicio de una narración densa (narra la historia de los niños Buscapé y Dadinho durante los años sesenta, setenta y ochenta), pero transparente, capaz de mostrarnos la belleza en medio de lo terrible (figura 11).

- El año que mis padres se fueron de vacaciones (Cao Hamburger, 2006): política (la dictadura militar) y fútbol (la euforia de la selección brasileña en la Copa del Mundo de fútbol en México 1970) sitúan el marco en el que se mueve la mirada de su protago- 
nista, Mauro, un niño de 12 años que se queda al cuidado de su abuelo, porque sus padres deben irse de "vacaciones".

\section{Bután}

- La copa (Khyentse Norbu, 1999): dos niños inician la vida monástica budista al pie del Himalaya, en donde el misticismo se mezcla con su pasión por el fútbol (con la Copa del Mundo de fútbol de Francia 1998 de fondo). Pequeña joya del cine oriental, simpática y sugerente, basada en hechos reales.

\section{Canadá}

- C.R.A.Z.Y. (Jean-Marc Vallée, 2005): original película que relata la infancia y adolescencia de Zach, el cuarto de una familia de cinco hermanos, con un problema de identidad sexual.

- Amerrika (Cherien Dabis, 2009): una inmigrante palestina y su hijo adolescente dejan Palestina y buscan una nueva vida en una pequeña ciudad de Illinois. Allí tendrán que esforzarse por encajar en una nueva cultura sin perder la propia, enfrentándose a un entorno que,

Figura 11. Ciudad de Dios (Fernando Meirelles, 2002).

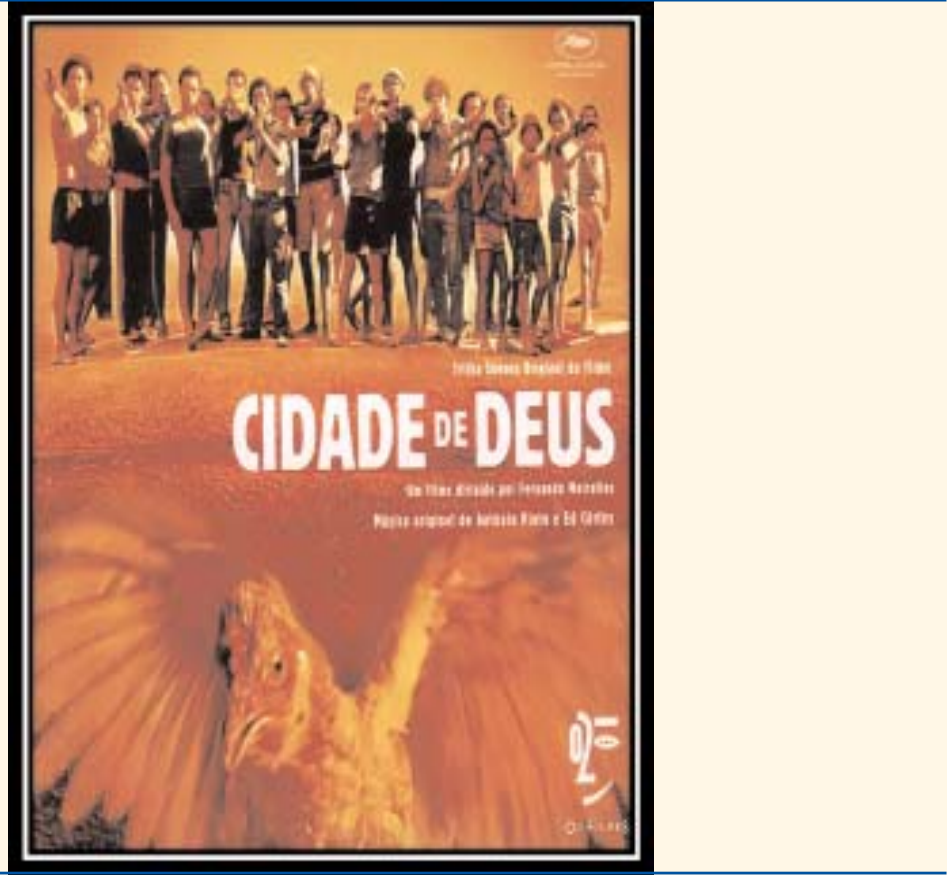


tras la invasión de Irak, mira con desconfianza a todo Oriente Medio.

Chile

- *Mon ami Machuca (Andrés Wood, 2004): dos niños de 11 años, Gonzalo, de clase acomodada, y Pedro Machuca, de un barrio ilegal, acuden al mismo colegio. A las dificultades objetivas de este intento de integración se agregan las que se derivan del clima que vive la sociedad chilena en el año 1973, época marcada por un gran resentimiento social y grandes conflictos. Excelen- te película, que nos deja muchas enseñanzas y valores (figura 12).

China

- Little red flowers (Zhang Yuan, 2006): la vida de Qiang, un niño de 4 años que es abandonado por su familia en un internado, situación habitual en la China revolucionaria, pues los padres así podían enrolarse en un trabajo de tiempo completo. Película repleta de la emoción que emanan los niños, sus caras y su naturalidad ante las cámaras.

Figura 12. Mon ami Machuca (Andrés Wood, 2004).

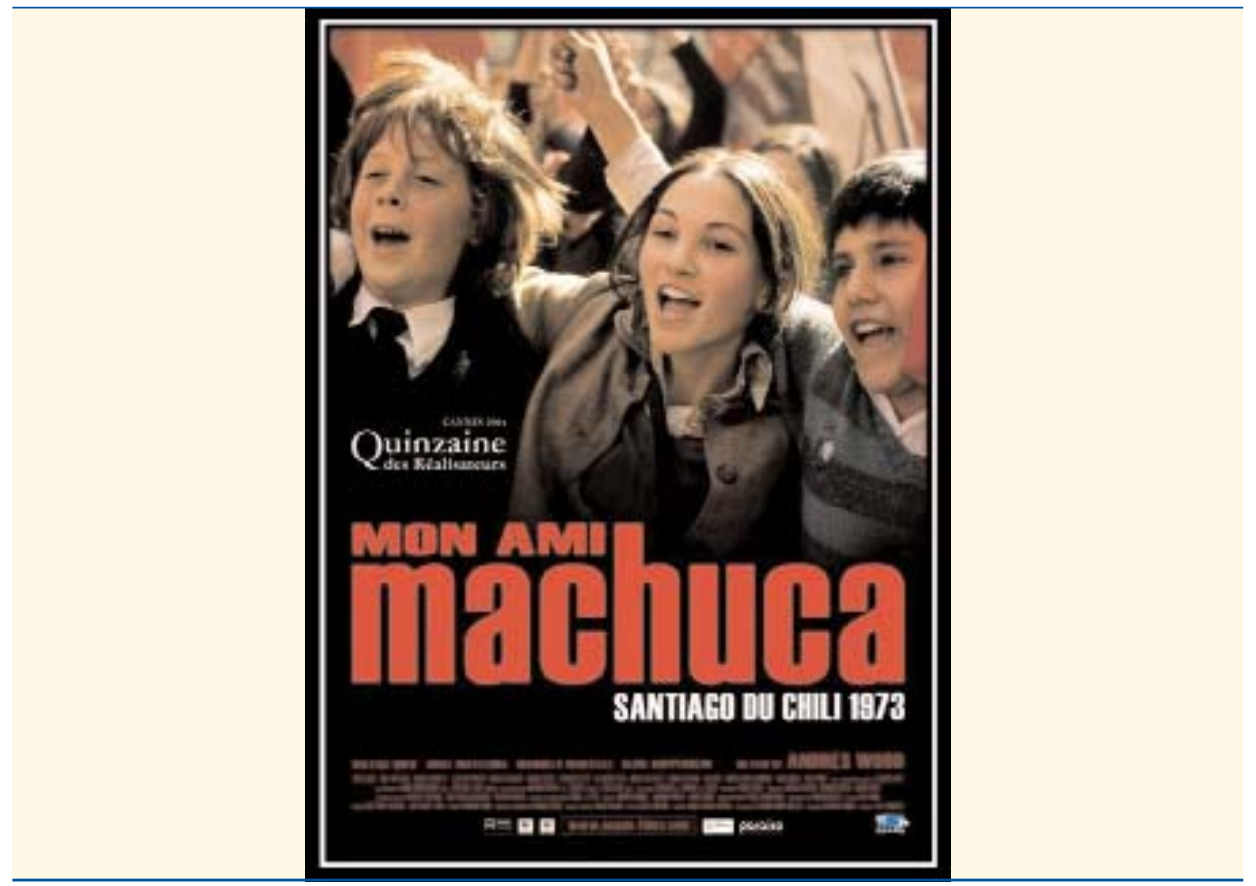




\section{Colombia}

- * La virgen de los sicarios (Barbet Schroeder, 2000): adaptación de la novela homónima de Fernando Vallejo, nos presenta la visión de los jóvenes sicarios y el mundo de la violencia alrededor de los cárteles de droga en Medellín. La película provocó en Colombia duras críticas por parte de los sectores conservadores de la sociedad por considerarla anticolombiana; sin embargo, las situaciones que se presentaban en la película no eran producto de la ficción y reflejan una problemática latente en los barrios marginados de la ciudad.

- *María llena eres de gracia (Joshua Marston, 2004): la joven de 17 años María vive con su familia en una pequeña población al norte de Bogotá y trabaja en una plantación de rosas. Su vida se complica al ser despedida del trabajo y quedar embarazada, momento en el que debe buscarse la vida y la enrolan para pasar drogas a Estados Unidos, tragando paquetitos de heroína. No es una historia sobre la droga, sino sobre la pobreza y el contraste entre las vidas

Figura 13. María llena eres de gracia (Joshua Marston, 2004).

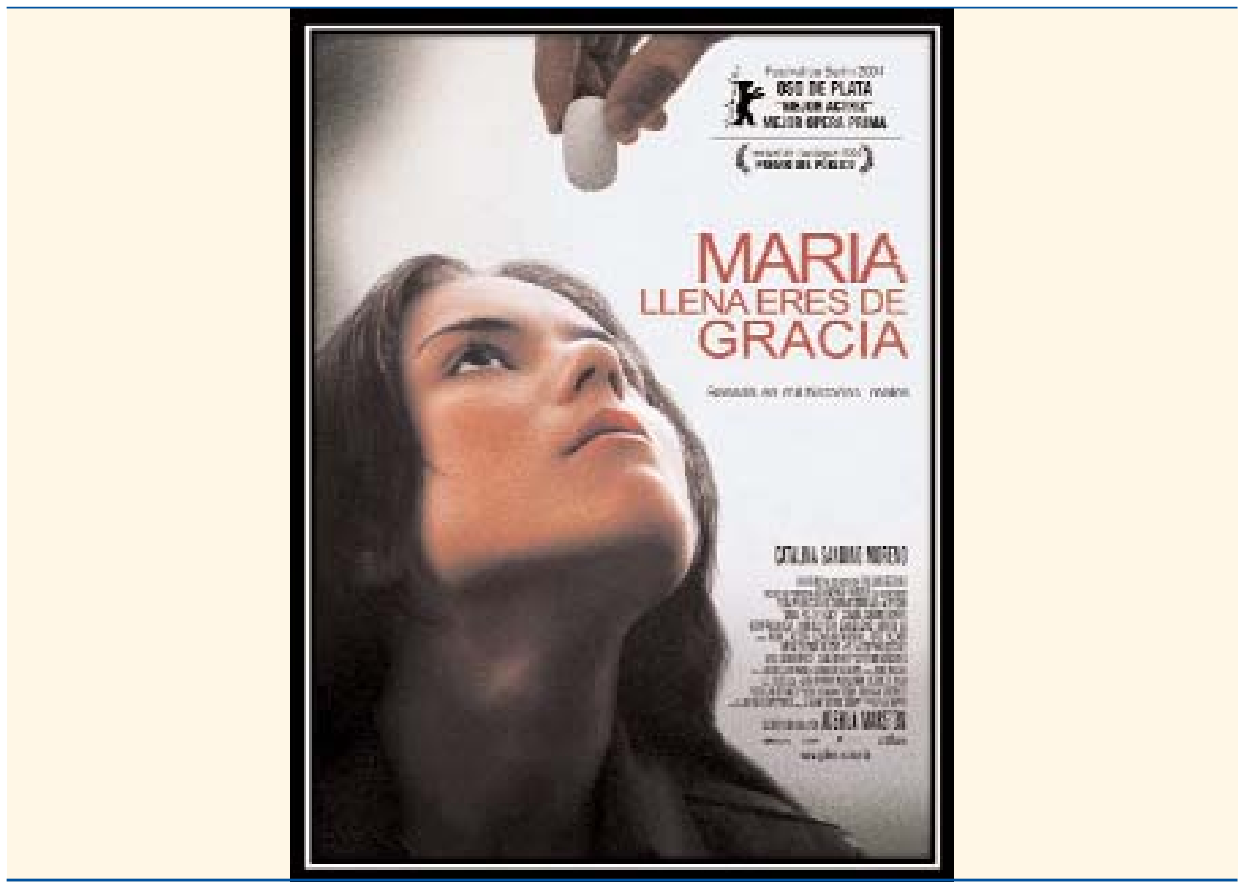


ahogadas por los límites del subdesarrollo, frente al incierto y poderoso sueño americano (figura 13).

\section{Corea del Sur}

- La mujer samaritana (Kim Ki-duk, 2004): retrato de dos amigas del instituto que desean viajar a Europa, para lo cual deben obtener dinero. Para ello una de ellas ejercerá de meretriz y su vida finaliza en tragedia; la otra amiga se siente culpable e intenta redimir su muerte devolviendo el dinero a los clientes que cobró.

\section{Dinamarca}

- Mundos aparte (Niels Arden Oplev, 2008): inspirada en una historia real de una joven de 17 años, testigo de Jehová, que se enamora de un chico que no pertenece a esa organización religiosa y deberá tomar una decisión: quedarse con su familia o con su amor. Película sobre fanatismos religiosos, tragedia emocional en donde los principios dogmáticos de esta organización chocan frontalmente con las decisiones del corazón de una joven adolescente.

\section{Grecia}

- Canino (Yorgos Lanthimos, 2010): un padre, la madre y sus tres hijos viven en una mansión a las afueras de una ciudad. Hay un cercado muy alto que rodea la casa, y los chicos nunca han salido de ella. Están siendo educados, entretenidos, aburridos y ejercitados con los métodos que sus padres juzgan apropiados, sin ninguna influencia del mundo exterior.

\section{India}

- Mi nombre es Khan (Karan Johar, 2010): un niño musulmán que se crió con su madre en Bombay y que sufre de síndrome de Asperger. Ya como un adulto se enamora de una hindú, madre soltera y que vive en San Francisco. Después de los atentados del 11-S, es detenido como sospechoso de terrorismo por las autoridades por la conducta sospechosa que tiene en razón de su discapacidad.

\section{Israel}

- Las tragedias de Nina (Savi Gabizon, 2004): un niño de 13 años tiene que hacer frente a su familia rota, al divorcio de sus padres, su padre moribundo y su temperamental madre, así como al haberse encaprichado de su tía. Tan divertida y trágica como la vida, es una comedia triste. 


\section{México}

- Partes usadas (Aaron Fernández, 2007): Iván es un muchacho de 14 años que vive con su tío, un mediocre comerciante de piezas usadas para coche que decide introducir a su sobrino en el robo de piezas. Interesante retrato de la vida de los delincuentes juveniles en México DF.

\section{Nueva Zelanda}

- Lovely bones (Peter Jackson, 2009): narra la historia de Susie Salmon, una niña de 14 años que, tras ser violada y asesinada a manos de su vecino, observa desde el cielo cómo su familia y amigos continúan con sus vidas. Desde allí, Susie intenta entender y asimilar por un lado, su muerte $y$, por otro, las decisiones y evolución de sus seres queridos.

\section{Serbia-Montenegro}

- Sueño de una noche de invierno (Goran Paskaljevic, 2004): un hombre ha pasado 10 años en la cárcel después de la Guerra de los Balcanes; al volver a su casa está ocupada por una mujer y su hija autista de 12 años, ambas refugiadas bosnias. La relación de estos tres marginados que quieren rehacer su vi- da contrasta con el "autismo" desarrollado por la propia sociedad serbia.

\section{Suecia}

- Lilja 4-ever (Lukas Moodysson, 2002): Lilja es una adolescente rusa de 16 años, abandonada por su madre, que lleva un vida miserable en una empobrecida ciudad de la antigua Unión Soviética. Rodeada de droga y miseria, la única manera que tiene de poder comer es vendiendo su cuerpo. La esperanza llega el día que conoce al atractivo Andrei, que le promete una vida mejor en Suecia.

\section{Venezuela}

- ${ }^{*}$ Maroa (Solveig Hoogesteijn, 2005): violencia infantil, delincuencia, maltrato infantil, analfabetismo, drogadicción, prostitución juvenil en Caracas visto bajo la preciosa mirada de una niña de 11 años, redimida por su afición natural por la música (figura 14).

\section{Otras películas sobre cine y pediatría para el recuerdo}

Los anteriores son algunos ejemplos de películas sobre cine y pediatría estrenadas en la última década. Todas con 
elementos formativos y docentes, que nos ayudan a conocer mejor a los niños y adolescentes que atendemos en nuestras consultas.

Pero no nos olvidamos de otras muchas estrenadas con anterioridad al año 2000. Muchas de ellas con un valor incluso superior a las previamente reseñadas en este texto.

En un breve y raudo repaso recordamos películas como Mandy (Alexander Mackendrick, 1952), Los 400 golpes (François Truffaut, 1959), Un sabor a miel (Tony Richardson, 1961), El milagro de Ana SuIlivan (Arthur Penn, 1962), Matar a un ruiseñor (Robert Mulligan, 1962), Del rosa al amarillo (Manuel Summer, 1963), El pequeño salvaje (François Truffaut, 1970), Verano del 42 (Robert Mulligan, 1971), El tambor de hojalata (Volker Schlöndorff, 1979), Mater amantísima (José Antonio Salgot, 1980), Adiós, muchachos (Louis Malle, 1987), ¿Quién te quiere, Babel? (Ignasi P. Ferré, 1987), El año del despertar (Gerard Corbiau, 1990), La piel que brilla (Philip Ridley, 1990), Alas de mariposa (Juanma Bajo Ulloa, 1991), El niño que gritó puta (Juan José Campanella, 1991), El aceite de la vida (George Miller, 1992), ¿A quién ama

Figura 14. Maroa (Solveig Hoogesteijn, 2005).

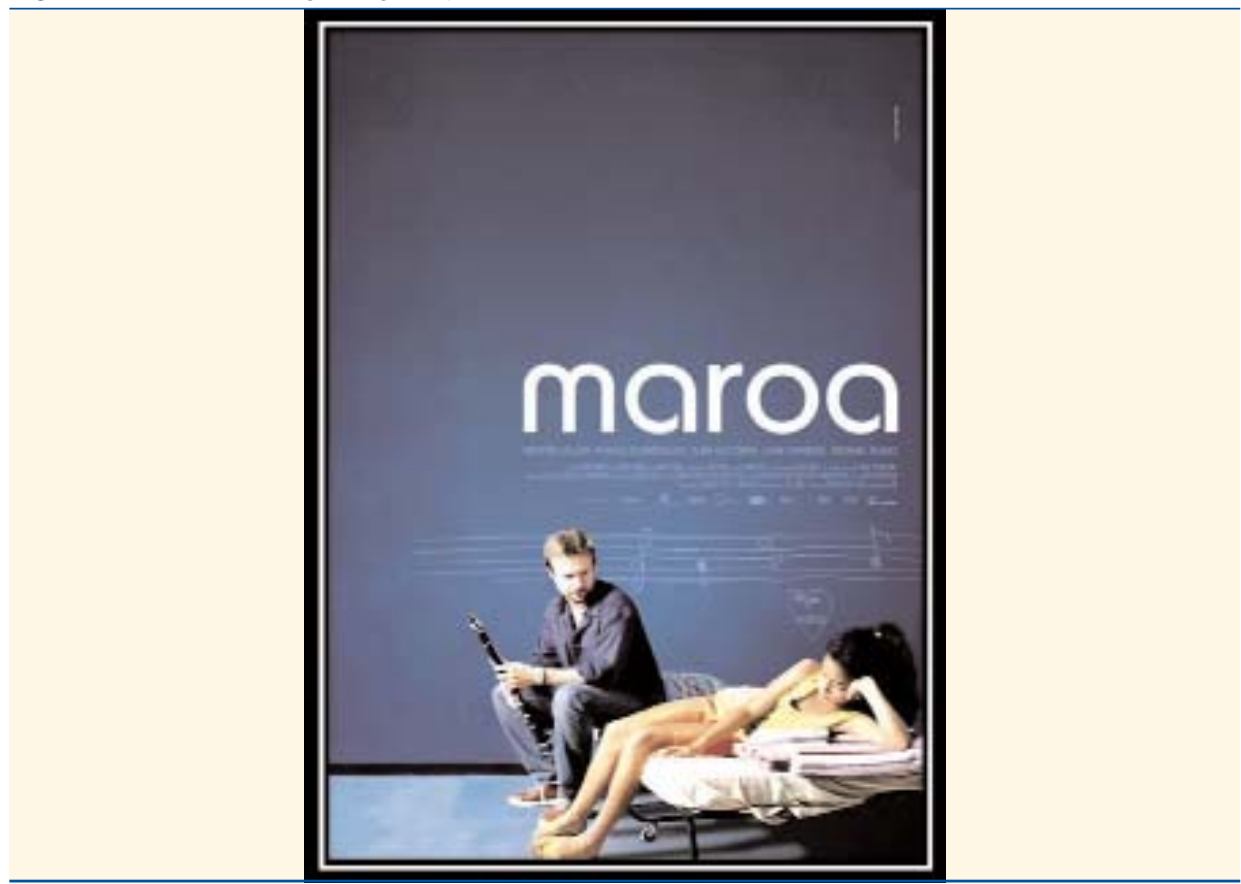


Gilbert Grape? (Lasse Hallström, 1993), La cometa azul (Tian Zhuangzhuang, 1993), La gran calabaza (Francesca Archiburgi, 1993), La madre muerta (Juanma Bajo Ulloa, 1993), Secretos del corazón (Montxo Armendáriz, 1993), Criaturas celestiales (Peter Jackson, 1994), Los juncos salvajes (André Techiné, 1994), Un testigo en silencio (Bruce Beresford, 1994), Círculo de amigos (Pat O'Connor, 1996), La buena vida (David Trueba, 1996), Fucking Amal (Lukas Moodysson, 1998), Patch Adams (Tom Shadyac, 1998), Un mundo a su medida (Peter Chelson, 1998), El verano de Kikujiro (Takeshi Kitano, 1999), La lengua de las mariposas (José Luis Cuerda, 1999), Las cenizas de Ángela (Alan Parker, 1999), Las vírgenes suicidas (Sofia Coppola, 1999), Ni uno menos (Xhang Yimou, 1999), Rosetta (Luc \& Jean-Pierre Dardenne, 1999), y un largo etcétera.

El cine: una afición que puede ser más que un entretenimiento, capaz de transmitir conocimientos, vivencias, experiencias... y despertar sentimientos en el espectador, quien a su vez interpreta la narración desde sus experiencias previas, al tiempo que se siente afectado por ella y la incorpora a su vida como una experiencia más propia. Una experiencia que nos pueda servir para ser, quizás, mejores personas; quizás, mejores médicos; qui- zás, mejores pediatras... O simplemente ser un buen motivo para el ocio. Cada uno elegirá lo que busca en el "séptimo arte", un arte que nació hace más de cien años en un elegante bulevar de París...

Si le gusta la propuesta, desde el blog Pediatría basada en pruebas (www.pediatriabasadaenpruebas.com/) continuaremos con nuestra cita de todos los sábados presentando entradas sobre Cine y Pediatría. Comenzamos esta aventura por casualidad, para aliviar el sesudo contenido del blog en los fines de semanas, a principios del año 2010. Hasta el momento hemos volcado diferentes contenidos:

- Los problemas de las infancias desfavorecidas: En el mundo, a cada rato: las prioridades de UNICEF en la infancia, Slumdog MiIlionaire: una fábula sobre infancias desfavorecidas.

- El síndrome de Down: La mirada del cine en español al síndrome de Down; Otras miradas del cine al síndrome de Down.

- La adopción infantil: La pequeña Lola nos adentra en las adopciones internacionales. La adopción revisada con distintas aristas: de Nordeste al Niño de marte, de La casa de los babys a La vergüenza. 
- La adolescencia y sus alrededores: Precious: adolescencia S.O.S.; La adolescencia bajo el prisma de Peter Jackson; Fish tank: desestructuración social, adolescencia frustrada.

- El comentario sobre ciertas enfermedades: La decisión de Anne: dilemas bioéticos, cáncer e infancia; $X X Y$ : algo más que el síndrome de Klinefelter.

- Especial cariño dedicamos a varios capítulos sobre la mirada de los ni- ños en el cine iraní: El minimalismo de Abbas Kiariostami, Sobre paraísos, espejos y tortugas, El extraordinario caso de la familia Makhmalbaf.

- Y otros más...

Aunque el cine constituye un puro entretenimiento, también creemos con convicción de que el "séptimo arte" es una buena oportunidad para la humanización de nuestra práctica clínica; en este caso orientada a la pediatría, a los niños y adolescentes. 